\title{
INTER-PARTNER CREDIBLE THREAT AND THE SURVIVAL OF U.S.-CHINA JOINT VENTURES
}

\author{
Jason Duan \\ Cameron University \\ Lawton, OK \\ Norma Juma \\ Washburn University \\ Topeka, KS
}

\begin{abstract}
International joint ventures ( $I J V$ s) are perceived as essential strategic weapons by which firms can transfer the complex complementary competencies needed for competitive advantage within firms' core markets and technologies. This study attempts to explore the relationship of inter-partner credible threat and the survival of IJVs in China. The study found that the existence of inter-partner credible threat, and high product relatedness between foreign parent and $I J V$, favorably influence the IJV's long-term survival.
\end{abstract}

\section{Introduction}

The proliferation of international joint ventures (IJVs) in emerging economies, particularly in China, in the last decade, has stimulated great research interest. They are perceived as increasingly important strategic weapons by which firms can transfer the complex complementary competencies needed for competitive advantage within firms' core markets and technologies (Harrigan, 1986). Beamish (1994) described joint ventures, the most common form of strategic alliance, as the dominant strategy used by multinational firms in emerging markets. International joint ventures have been widely considered as hybrid forms of organizations which aim to bring together complementary skills, know-how and resources of two or more parent firms to accomplish specific objectives. The cross-cultural and inter-firm nature of IJVs are key sources of the additional complexities and challenges in the management of an IJV.

Although IJVs have become increasingly important in emerging markets, a high level of dissatisfaction with actual outcomes relative to expectations has been reported (Hitt, Levitas, Arregle \& Borza, 2000; Madhok \& Tallman, 1998). Of the particularly critical decisions, partner selection has been seen as especially important to a venture's success (Geringer, 1988; Saxton, 1997). In an international setting, differences in culture, infrastructure, economic development, and government policies increase the complexity and the vitality of the partner 
selection (Dacin, Hitt \& Levitas, 1997). However, previous empirical studies on partner selection tend to focus on the organizational characteristics of partners, such as strategic symmetry (Harrigan, 1988), inter-firm diversity (Parkhe, 1991), match of partner characteristics (Geringer, 1988), and inter-partner compatibility (Beamish, 1988; Hill \& Hellriegel, 1994; Inkpen, 1995; Inkpen \& Currall, 1998). In essence, the emphasis is on the cooperative aspects of venture partners. The use of economic constraints and mechanisms such as the inter-partner credible threat in curbing opportunistic behavior of partners, and its impact on the venture's performance, have not fully been explored. Following the tradition of game theory application in the study of joint ventures (Heide \& Miner, 1992; Parkhe, 1991), Zhang and Rajagopalan (2002) argued that inter-partner credible threat plays a more important role than partners' management control in determining partners' payoff in IJVs. He defines inter-partner credible threat as the certainty of either partner's retaliation given that the other partner cheated earlier (Zhang $\&$ Rajagopalan, 2002). The existence of inter-partner credible threat will not only reduce IJVs coordination costs, but also enhance partners' cooperative behaviors and result in better performance. Coordination costs are the expenses in monetary terms, as well as managerial time and effort that the partners incur in the process of composing tasks and coordinating activities across organizational boundaries (Zhang \& Rajagopalan, 2002).

This study attempts to test the theoretical predications on the use of inter-partner threat and its impact on IJV performance. After the introduction, we briefly review the literature of joint venture partner selection and joint venture performance. Then we develop our hypotheses. Next we describe our sample and research method, followed by a discussion of the statistical analysis. Then we conclude with the theoretical and practical implications of the study.

\section{International Joint Venture Partner Selection and Performance}

The analysis of IJV performance determinants and their relationships with local partner selection has commanded considerable research efforts in the past. Previous research has progressed along two main theoretical paths. First, some researchers have focused on resources exchange and the value of the resource accessed in an IJV (Saxton, 1997). Geringer (1988) argued that selection of an IJV partner should consider a fit, both for task-related characteristics (e.g., resources and skills) and for partner-related characteristics (e.g. size, objectives, and operating policies). Harrigan (1986) proposed that IJV performance depends on strategic symmetry between the partners, which occurs when they "possess complementary strategic missions, resource capabilities, managerial capabilities, and other attributes that have a strategic fit such that the relative bargaining power of the partners is evenly matched" (Harrigan, 1986, pp. 11).

Using variables of inter-partner relatedness, parent-venture relatedness, and the relative size, nationality, and IJV experiences of the parent firms, Harrigan reported positive relationships between partners' strategic symmetry and venture survival (Harrigan, 1988). Hitt et al. (2000) provided some evidence to support 
the resource-based perspective as to why firms select particular partner. Their study showed that emerging market firms emphasized the partner's financial assets, technical capabilities, and intangible assets, whereas developed market firms emphasized the partner's unique competencies and local market knowledge and access.

Other researchers have focused on the interactive nature of cooperation between the partners in the ventures (Heide \& Miner, 1992; Parkhe, 1991; Saxton, 1997). Researchers in this tradition emphasize the use of economic and social mechanism to sustain the ongoing relationship between the partners involved, not the resource per se. Partners within IJVs are assumed to have the potential for opportunistic behavior (Reich \& Mankin, 1986). The use of economic constraints, such as the investment of specific assets and other arrangements, may reduce the potential for opportunism by locking partners into a strategic alliance, with the expected long-term gains from maintaining the relationship exceeding the potential short-term gains from opportunism (Parkhe, 1993). Zhang and Rajagopalan (2002) proposed that inter-partner credible threat, as defined as 'the certainty of either partner's retaliation given the other partner's earlier cheating,' may serve as an effective mechanism to curb the potential opportunism of partners, and consequently affect the venture's performance.

In reviewing previous research, we have founded that insufficient attention has been paid to empirical study testing the effectiveness of economic constraints to enhance cooperative behavior of partners. In this study, we attempt to examine the inter-partner credible threat as a deterrence mechanism and its effect on the performance of IJVs.

\section{Hypotheses}

To explore and identify the key ingredients of successful IJVs is of paramount importance to IJV researchers as well as to IJV practitioners. The measurement of the performance of IJVs itself has been an important research topic in the field of international management (Arino, 2003; Geringer \& Hebert, 1991; Olk, 2002; Yan \& Zeng, 1999). The validity of the different measures has been questionable (Arino, 2003; Olk, 2002). For example, many researchers have used the IJVs' survival as a proxy of their performance measure (Harrigan, 1988; Hennart, Kim \& Zeng, 1998; Li, 1995; Makino \& Beamish, 1998). Although Geringer and Hebert (1989) have found a significant positive correlation between objective measures using survival, stability and duration, and subjective measures of performance, Arino (2003) argued that operational measures of strategic alliance performance, such as survival or longevity, can be related to performance only in particular instances. These instances require some knowledge of the temporal nature of the partners' goals for the [JVs. Because exit/termination of an IJV may be anticipated or "planned" by the partners, from the outset (Inkpen \& Beamish, 1997), previous empirical studies that simply count the death rate, without the knowledge of the founding partners' intentions, were conceptually flawed (Yan \& Zeng, 1999). Therefore, in this 
study, we use IJVs' survival rates against a pre-determined duration to measure IJVs' performance. A detailed discussion of this measure will be presented in the following section.

The construct, inter-partner credible threat, is derived from a game theory framework (Zhang \& Rajagopalan, 2002). Zhang and Rajagopalan illustrates the inter-partner credible threat using a one-stage 'prisoner's dilemma' model and an infinitely repeated 'prisoner's dilemma' model. In essence, the existence of credible threat in an ongoing cooperative relationship will reduce the coordination cost between partners, by aligning the incentive/payoff of partners. For instance, in the one-stage prisoner's dilemma, the two sponsoring firms simultaneously choose a strategy to control the IJV (high level control vs. low level control). If both partners choose the high level control strategy, then the payoff will be relatively low, due to the high coordination costs. On other hand, if both partners choose low level, then the payoff will be relatively high, due to the low coordination costs. Since most IJV partners have different, and often conflicting interests, it is highly unlikely that they would voluntarily opt for the low level control. Given these differences, each partner may choose to maximize their own payoffs rather than the overall payoffs. This reduces IJVs to 'forums of rivalrous control' (Zhang \& Rajagopalan, 2002). Zhang and Rajagopalan suggest that interpartner credible threat can break this circle of rivalrous control. Partners will have to weigh the payoffs from cooperation and cheating. Partners will tend to stick to the cooperative strategy as long as payoffs from cooperation outweigh those from cheating. This will increase the overall payoffs of the IJV and its overall performance and longevity. Because this mechanism does not require substantial investment in relationship building and coordination, the long term economic efficiency can positively affect the IJV's performance. Therefore, we developed the following hypothesis:

\section{Hypothesis 1: The existence of credible threat from either or both part- ners will have a positive influence on the IJV's survival.}

The effect of equity ownership on the survival of IJVs has been studied by many researchers (Dhanaraj \& Beamish, 2004; Makino \& Beamish, 1998). Teece (1992) notes, 'equity stakes provide a mechanism for distributing residuals when ex ante contractual agreement cannot be written to specify or enforce a division of returns.' The commitment to jointly own the venture, and the degree of control over its operation, as decided by the equity position, places the partners in a mutual hostage situation, whereby opportunistic behavior of partners can be mitigated (Dhanaraj \& Beamish, 2004; Williamson, 1985). Makino and Beamish (1998) argued that the choice of desired ownership level reflects the interplay between the parent firms' desire to secure control and their attitudes towards investment risks. Their empirical study showed that the ownership structures of Japanese JVs have significant impact on IJVs' performance and survival. Foreigner partners with significant equity shares ultimately have more control 
of the venture through voting rights, hence they do hold a credible threat over the local partners. The local partners, on the other hand, have the legislative backing of the Chinese government. The cost of liquidating a venture in China can be quite high in terms of legal fees, time and effort (Zhang \& Rajagopalan, 2002). Hence, with or without a voting majority, the local partners in China do hold a credible threat. In the above given scenario, it is highly unlikely that either party will engage in opportunistic behavior. According to Zhang \& Rajagopalan's (2002) framework, this scenario is likely to present a successful IJV, in which both partners cooperate and achieve balanced payoffs. Therefore, we offer the following hypothesis:

Hypothesis 2: Equity ownership of the foreign parent firm in the IJV will be positively related to the IJV survival.

Previous studies have shown that a product diversification relationship between parent firms and the IJV can influence the venture's economies of scale and scope (Harrigan, 1986; Luo, 1997). This relationship may also affect the IJV's ability to develop the market and products in the host country or international markets, because product relatedness between the parent firm and the IJV will determine the likelihood of how much industrial experience, parent firm's intangible assets available to the new venture, and product relatedness between the local firm and the IJV will determine the established distribution channels, production facilities and skilled labors utilizable by the new venture (Geringer \& Herbert, 1989). Therefore, we offer the following hypothesis:

Hypothesis 3: An IJV with a product related with that of its foreign parent firm or its local parent firm has a favorable influence on the IJV survival.

\section{Methodology}

In this study we test a sample of 216 U.S.-China joint ventures by using logistical regression model. The data consists of a sample of IJVs established in China prior to 1989 (excluding service ventures and those IJVs with multiple foreign partners). The data is compiled from the published Almanac of China's Foreign Economic Relations and Trade (MOFTEC 1984-1989 editions) and from a Directory of U.S. Firms Operating in China (2000 edition). Thus these IJVs represent the "early birds" of American investment in China. There are two reasons why this sample set is appropriate to this study. First, the Tiananmen Square incident in 1989 created an unexpected disturbance in the flow of foreign investment into China because investors began to doubt China's political stability. Moreover, the Chinese government launched an economic adjustment program in early 1989 , which aimed to control rapidly rising inflation through a reduction in aggregate demand, leading to a halt of all new investment projects and to the suspension or delay of the approval of negotiated foreign investment 
agreements, including IJVs (Zhang, 2001). Therefore, we select 1989 as a cutoff point, as it clearly marked the first stage of foreign investment in China. Second, in order to measure IJV performance, particularly using survival as a proxy of performance, the relative time frame needs to permit IJVs operating long enough to prove their performance. Therefore, when we examine the sample IJVs' survival rate in 2000, the latest ventures formed in 1988 have twelve years to prove their performances.

\section{Dependent variable}

The dependent measure in this study is the survival of IJVs established prior to 1989. By examining a Directory of U.S. Firms Operating in China (2000 edition), we identify the exit/termination rate of U.S.-China joint ventures. Several researchers have used the same method to investigate foreign investments in the United States and South Asia (Harrigan, 1988; Makino \& Beamish, 1998; Shaver, Mitchell \& Yeung, 1997; Yamawaki, 1997). Among 216 entries of IJVs, 50 of them still exist, a survival rate of approximately 23 percent. However, we should take this seemingly low survival rate with caution. An IJV agreement in China usually stipulates a fixed duration. This is negotiated by the founding partners before approval of the agreement by the Chinese government. The duration means that the foreign partners agree to liquidate their share in the IJV to the Chinese partner (s) at a pre-specified time. The standard duration is 15-30 years. Recently, the Chinese government has changed the policy and allowed the contracted parties to extend the duration. By examining the non-survival ventures against their pre-determined contract duration, only $51 \%$ ( 85 firms) of them were short-lived before their duration expired. $49 \%$ ( 81 firms) reached their expiry duration. Although one can argue that a pre-specified duration may be a political necessity to please the Chinese government, we believe that the length of duration negotiated in the IJV agreement does provide some information on the foreign partner's intention, at least in the venture's formation stage. Therefore, we could not conclude that these $81 \mathrm{IJVs}$ had failed because their poor performance. They may well serve the venture partners' initial strategic objectives and fulfill their mission to be a "real option" for their partners to get into an uncertain new market (Chi \& Seth, 2002; Kogut, 1991). The short-lived 85 IJVs, representing a $39 \%$ of total entries, were probably true failures.

\section{Independent variables}

The major independent variable we use in this study is the existence of credible threat from either or both partners in the IJV. The variable is coded one if there is credible threat (or zero otherwise). Based on a four cases study of Japan-China joint ventures, Zhang and Rajagopalan (2002) have identified some specific sources of inter-partner credible threat in an IJV, such as asset specificity, business expertise, and political authority. In this study, we follow Zhang and Rajagopalan's approach, by examining asset specificity, business expertise, and political authority in each U.S.-China venture. Our assessments are mainly based 
on information in an IJV agreement. Archive information and case studies on some IJVs have also been used.

The second independent variable is equity position of the foreign parent firm. We use the percentage of American parent equity in the IJV as reported by the data source. We use two independent variables to examine the product relatedness on the IJVs survival. The first measures the product relatedness between the American parent and the IJV, and the second measures the product relatedness between the Chinese parent and the IJV. Both measures of the product relatedness are assessed based on the Standard Industry Code at four-digit level.

Following previous empirical studies, we also use three control variables. One control variable is location. In an emerging economy, such as China, the level of establishment of a free market structure, and other institutional infrastructures varies across different regions. Consequently, the degree of location advantage enjoyed by most IJVs may have differential impacts on their performance (Pan \& Chi, 1999). Since 1979, China has adopted the idea of "gradualism" in opening its door to foreign investments. Starting with the experiments in the first four specialized economic zones (SEZs), the Chinese government has granted favorable economic policies, tax incentives and regulations with respect to foreign investments. Later, the government has gradually expanded such favorable policies and regulations to the fourteen coastal cities and trade development zones. These designated locations offer various conveniences and incentives for foreign firms, thus increasing the likelihood that an IJV would survive. A dummy variable is coded one if the IJV is located in one of the special economic zones or original fourteen open cities (zero otherwise).

The second control variable is the amount of the American partner's investment in the IJV. The amount of investment may not only reflect the resource commitment and risk orientation of American parent in the IJV, but also represent a hurdle factor for American parent to terminate the partnership pre-maturely. Therefore we believe that the larger the amount an American parent invested in a venture, the more likely the venture would survive.

Finally, we use IJV duration as a control variable to gauge the survival of IJV. As argued previously, an IJV's pre-determined duration should have a positive relationship with respect to the IJV survival, all other factors being equal. If an IJV is short-lived before its pre-determined duration expiry, it should be an indication of not very successful operations. If an IJV survives after its pre-determined duration, we can argue that the venture must be satisfactory to both partners, otherwise they can simply terminate the venture according to the agreement. A description of variables and their correlations is presented in Table 1.

\section{Regression Results}

The dependent variable, survival, is a binary variable taking value one or zero only. We use a SAS program to run the regression and report our results in Table 2. 
Table 1

Descriptive statistics and product moment correlations (216 cases)

\begin{tabular}{lcccccccc}
\hline & 1 & $\mathbf{2}$ & $\mathbf{3}$ & $\mathbf{4}$ & $\mathbf{5}$ & $\mathbf{6}$ & $\mathbf{7}$ & $\mathbf{8}$ \\
\hline 1. Survival & 1 & & & & & & & \\
2. Threat & 0.81 & 1 & & & & & & \\
3. Equity & 0.24 & 0.31 & 1 & & & & & \\
4. Product I & 0.46 & 0.40 & 0.22 & 1 & & & & \\
5. Product II & 0.00 & -0.07 & -0.19 & -0.16 & 1 & & & \\
6. Location & -0.07 & -0.04 & 0.07 & 0.05 & -0.21 & 1 & & \\
7. Duration & 0.29 & 0.27 & 0.37 & 0.46 & -0.11 & 0.15 & 1 & \\
8. Amount & 0.28 & 0.24 & 0.19 & 0.32 & 0.09 & 0.17 & 0.35 & 1 \\
Mean & 0.23 & 0.25 & 43.07 & 0.57 & 0.86 & 0.17 & 15.46 & 189.29 \\
Standard Error & 0.03 & 0.03 & 0.87 & 0.03 & 0.02 & 0.03 & 0.38 & 23.02 \\
Minimum & 0.00 & 0.00 & 25 & 0.00 & 0.00 & 0.00 & 2 & 3 \\
Maximum & 1.00 & 1.00 & 95 & 1.00 & 1.00 & 1.00 & 30 & 3198 \\
\hline
\end{tabular}

Table 2

Binary Logistic Regression Results

\begin{tabular}{lcc}
\hline Variables & Estimate & Standard Error \\
\hline Intercept & 2.490 & 1.549 \\
Threat & $2.473^{*}$ & 0.375 \\
Equity & 0.030 & 0.029 \\
Product I & $1.725^{* *}$ & 0.593 \\
Product II & 0.442 & 0.446 \\
Location & -0.393 & 0.491 \\
Duration & -0.054 & 0.063 \\
Amount & -0.002 & 0.001 \\
\hline
\end{tabular}

* $p<0,0001$

The estimated coefficients of variable Threat, Product I are positively significant. Therefore Hypothesis 1 and Hypothesis 3 are supported by the statistical tests. The estimated coefficients of other variables are not statistically significant. 
Therefore we could not reject the null hypotheses that these variables have no influences on the IJV's survival. The results show that the existence of inter-partner credible threat, between the venture partners, contributes significantly to the survival of U.S.-China joint ventures. The relatedness of an IJJV's product to its American parent firm also has a positive influence on the venture's survival. However, our tests do not support the effect of equity ownership on the survival of an IJV. One explanation is that, as presented by a recent study (Dhanaraj \& Beamish, 2004), the relationship between equity ownership and mortality of IJV may be nonlinear and asymmetrical. Therefore, our linear logistic regression model did not capture the nonlinear effect. With respect to the three control variables, we were surprised that none of them are statistically significant. Our results are not consistent with the results of a previous study using financial measures of performance of IJVs (Pan \& Chi, 1999).

\section{Discussion and Conclusions}

This study attempts to explore the relationship of inter-partner credible threat on the survival of international joint ventures. The study concludes that the existence of inter-partner credible threat, and the high product relatedness between the foreign parent and the IJV, favorably influence the IJV's long-term survival. The contributions of this study to the existing research are as follows.

First, since the publication of Zhang and Rajagopalan's theoretical work (2002), this study is the first to establish an empirical test to support their theoretical arguments. Therefore, this study not only validates an important theory construct in IJV literature, but also contributes to our more comprehensive view of partner selection and IJV performance.

Second, this study is the first reported in the literature that has attempted to incorporate a control variable with the temporal nature of partners' expectations to measure performance. Although the coefficient of this control variable is not statistically significant, the result answers the critique of using survival as a performance measure.

Third, this study has provided evidence to support the previous research that claims the relationship between foreign parent equity ownership and mortality rate of IJV may not be linear. Therefore, a fine-grained analysis of the role of foreign equity ownership is warranted for future study. This study's empirical analysis will present important managerial implications. Because the existence of inter-partner credible threat may serve as a self-reinforced mechanism to sustain partners' cooperative behavior and deter partners' opportunistic behavior, multinational firms may appropriately structure an IJV to minimize the cost of coordination and safeguard appropriation concerns simultaneously (Zhang \& Rajagopalan, 2002). While previous studies emphasized resource sharing between partners, this study calls for carefully aligning the partners' incentives without resort to resource investment.

However, there are many limitations in this study. First of all, the key variable, inter-partner credible threat, needs to be further refined. Our assessment, 
based on partner's asset specificity, business expertise, and political authority, is subjective and preliminary. Future research may test the variable, based on survey questions and using data on IJVs in other developing countries. Second, because of the data constraints, some variables may have been omitted in our regression model. For example, trust is considered to be a central feature of a strategic partnership (Mohr \& Spekman, 1994). Doz (1996) found that alliances that have developed trusting relationships over time are more likely to survive for longer periods of time. Although Zhang and Rajagopalan (2002) argued that inter-partner credible threat is a more critical factor than trust in IJVs, a future study along this line may consider including variables such as trust to validate the results of this analysis.

\section{References}

Anderson, E., \& Gatignon, H. (1986). Modes of foreign entry: A transaction cost of analysis and propositions. Journal of International Business Studies. Fall, 1-26.

Arino, A. (2003). Measures of strategic alliance performance: An analysis of construct validity. Journal of International Business Studies. 34(1), 66-79.

Beamish, P. W. (1994). Joint ventures in LDCs: Partner selection and performance. Management International Review: 2, 60-74.

Beamish, P. W. (1988). Multinational joint ventures in developing countries. New York: Routledge.

Chi, T., \& Roehl, T. W. (1997). The structuring of interfirm exchanges in business knowhow: Evidence from international collaborative ventures. Managerial and Decision Economics. 18, 279-294.

Chi, T., \& Seth, A. (2002). Joint ventures through a real options lens. In F.J. Contractor \& P. Lorange (Eds.), Cooperative strategies and alliances. (pp. 71-87). Kidlington, UK: Elsevier.

Dacin, M. T., Hitt, M. A., \& Levitas, E. (1997). Selecting partners for successful international alliances: Examination of U.S. and Korean firms. Journal of World Business. $32(1), 3-16$.

Dhanaraj, C., \& Beamish, P. W. (2004). Effect of equity ownership on the survival of international joint ventures. Strategic Management Journal. 25(3), 295-306.

Doney, P. M., Cannon, J. P., \& Mullen, M. R. (1998). Understanding the influence of national culture on the development of trust. Academy of Management Review. 23, $601-620$.

Doz, Y. (1996). The evolution of cooperation in strategic alliances: Initial conditions or learning processes. Strategic Management Journal. 17, 55-83. 
Dunning, J. H. (1988). The eclectic paradigm of international production: A restatement and some possible extensions. Journal of International Business Studies. 19(1), 1-31.

Erramilli, M. K. (1996). Nationality and subsidiary ownership patterns in multinational corporations. Journal of International Business Studies. 27(3), 225-248.

Gatignon, H., \& Anderson, E. (1988). The multinational corporation's degree of control over foreign subsidiaries: An empirical test of a transaction cost explanation. Journal of Law, Economics, and Organization, 4(2), 305-236.

Geringer, J. M., \& Hebert, L.(1989). Control and performance of international joint ventures. Journal of International Business Studies, 20, 235-254.

Geringer, J. M. (1991). Measuring performance of international joint ventures. Journal of International Business Studies. 22(2), 249-264.

Geringer, J. M. (1988). Joint venture partner selection: Strategies for developed countries. Westport, NY: Quorum Books.

Harrigan, K. R. (1986). Managing for joint venture performance. Lexington, MA: Lexington Books.

Harrigan, K. R. (1988). Strategic alliances and partner asymmetries. In F. J. Contractor, \& P. Lorange (Eds.), Cooperative Strategies in International Business. (pp. 205-226). Lexington, MA: Lexington Books.

Heide, J. B., \& Miner, A. S. (1992). The shadow of the future: Effects of anticipated interaction and frequency of contact on buyer-seller cooperation. Academy of $\mathrm{Ma}$ nagement Journal, 35, 265-291.

Hennart, J. F., Kim, D. J., \& Zeng, M. (1998). The impact of joint venture status on the longevity of Japanese stakes in U.S. manufacturing affiliates. Organization Science, 9(3), 382-395.

Hennart, J. F. (1991). The transaction cost theory of joint ventures: An empirical study of Japanese subsidiaries in the United States. Management Science, 37, 483-497.

Hill, R. C., \& Hellriegel, D., (1994). Critical contingencies in joint venture management: Some lessons from managers. Organization science, 5(4), 594-607.

Hitt, M. A., Levitas, E., Arregle, J., \& Borza, A. (2000). Partner selection in emerging and developed market contexts: Resource-based and organizational learning perspective. Academy of Management Journal, 43, 449-467.

Inkpen, A. C., \& Beamish, P. W. (1997). Knowledge, bargaining power and international joint venture instability. Academy of Management Review, 22(1), 177-202. 
Inkpen, A. C., \& Currall, S. C. (1998). The nature, antecedents, and consequences of joint venture trust. Joturnal of International Management, 4(1), 1-20.

Inkpen, A. C. (1995). The management of international joint ventures: An organizational learning perspective. London: Routledge.

Kogut, B. (1991). Joint ventures and the option to expand and acquire. Management Science, 37(l), 19-33.

Li, J. (1995). Foreign entry and survival: Effects of strategic choices on performance in international markets. Strategic Management Journal, 16, 333-351.

Luo, Y. (1997). Partner selection and venturing success: The case of joint ventures with firms in the People's Republic of China. Organization Science, 8(6), 648-650.

Madhok, A., \& Tallman, S. D. (1998). Resources, transactions and risks: Managing value through interfirm collaborative relationships. Organization Science, 9, 326-339.

Makino, S., \& Beamish, P. W. (1998). Performance and survival of joint ventures with non-conventional ownership structures. Journal of International Business Studies, 29(4), 797-818.

Mohr, I., \& Spekman, R. (1994). Characteristics of partnership success: Partnership attributes, communication, behavior and conflict resolution techniques. Strategic Management Journal, 15, 135-152.

Olk, P. (2002). Evaluating strategic alliance performance. In F. J. Contractor, \& P. Lorange (Eds.), Cooperative Strategies and Alliances, (pp. 119-143). Kidlington, UK: Elsevier.

Pan, Y. (1996). Influences on foreign equity ownership level in joint ventures in China. Journal of International Business Studies, 27(1), 1-26.

Pan, Y., \& Chi, S. K. (1999). Financial performance and survival of multinational corporations in China. Strategic Management Journal, 20, 359-374.

Parkhe, A. (1991). Interfirm diversity, organizational learning, and longevity in global strategic alliances. Journal of International Business Studies, 22, 579-601.

Parkhe, A. (1993). Strategic alliance structuring: A game theoretic and transactional cost examination of interfirm cooperation. Academy of Management Journal, 36, 794-829.

Reich, R., \& Mankin, E. (1986). Joint venture with Japan give away our future. Harvard Business Review, 64, 77-86.

Saxton, T. (1997). The effects of partner and relationship characteristics on alliance outcomes. Academy of Management Journal, 40(2), 443-461. 
Schaan, J. (1988). How to control a joint venture even as a minority partner. Journal of General Management, 14(1), 4-16.

Shan, W. (1991). Environmental risks and joint venture sharing arrangements. Journal of International Business Studies, 22(4), 555-578.

Shaver, J. M, Mitchell, W., \& Yeung, B. (1997). The effect of own-firm and other firm experience on foreign direct investment survival in the United States, 1987-92. Strategic Management Journal, 18, 811-824.

Teece D. (1992). Competition, cooperation and innovation. Journal of Economic Behavior and Organization, 18, 1-25.

Tung, R. L. (1984). Business negotiations with the Japanese. Lexington, MA: Lexington Books.

Williamson, O. E. (1985). The economic institutions of capitalism. New York: Free Press.

Yamawaki, H. (1997). Exit of Japanese multinationals in U.S. and European manufacturing industries. In P. Buckley \& J. L. Mucchielli (Eds.), Multinational Firms and International Relation, (pp. 220-237). Cheltenham, UK: Edward Elgar.

Yan, A. (1998). Structural stability and reconfiguration of international joint ventures. Journal of International Business Studies, 29(4), 773-796.

Yan, A., \& Zeng, M. (1999). International joint venture instability: A critique of previous research, a reconceptualization, and directions for future research. Journal of International Business Studies, 29(4), 773-796.

Zhang, Y., \& Rajagopalan, N. (2002). Inter-partner credible threat in international joint ventures: An infinitely repeated prisoner's dilemma model. Journal of International Business Studies, 33(3), 457-478.

Zhang, K. H. (2001). What explains the boom of foreign direct investment in China? Economia Internationale. 54(2), 251-274.

Jason Duan is an assistant professor of management at Cameron University. He received his Ph.D. and MBA from the University of Illinois at Urbana-Champaign. His primary research interests include technology entrepreneurship, international joint ventures, foreign direct investment and Asian business. His articles have appeared in journals including Asia Pacific Journal of Management, Journal of Applied Management and Entrepreneurship, and Midwestern Business and Economic Review.

Norma Juma received a bachelor of business administration (BBA) from Mysore University, India and Masters in Business Administration (MBA) from 
Pondicherry University, India. Her research interest includes Intellectual Capital, Strategic Alliances and topics pertaining to new ventures. Norma's work has been presented at international, national and regional conferences. Her research as appeared in the International Journal of Innovation Management, International Journal of Information Technology and Management amongst others and a number of conference proceedings. 